\title{
MUNICIPAL PROGRESS: 1904-1905
}

\section{By Hon. Clinton Rogers Woodruff.}

Secretary National Municipal League.

For some years there has been a slowly growing conviction that the trend in municipal affairs in our American cities is toward improvement-a conviction which was materially strengthened by the results of the elections of November, I905.

In New York, District Attorney Jerome was re-elected by a substantial plurality, although he was not the nominee of either of the three parties in the field and had no permanent or far-reaching organization at his command. This demonstration of the power of the people was most impressive and illustrates what can be accomplished when they are thoroughly aroused, but it is not to be concluded that it will be possible to repeat the experiment successfully year after year, because the conditions surrounding our municipal elections are such as to make independent demonstrations most difficult.

The Jerome vote is significant, however, of the voters' growing independence of party lines and of their dissatisfaction with existing conditions. The large vote for William $\mathrm{R}$. Hearst and his colleagues of the Municipal Ownership ticket tells the same story. No one in the summer months of 1905 anticipated that there would be any great amount of interest in the New York mayoralty campaign. The renomination of Mayor McClellan was a foregone conclusion. The fact that his administration had been free from conspicuous scandals and was generally conceded to be one of the most, if not the most, efficient under Tammany rule, and the further fact that New York was normally Democratic, created the impression that Tammany would prevail by a safe majority and elect its whole ticket. The subsequent failure of the opposition forces to fuse tended to strengthen the belief in McClellan's easy re-election.

( $19 \mathrm{I})$ 
Political leaders failed to take into consideration, however, the great and spreading discontent of the masses with "boss" rule and with the prevailing conditions which, in their minds, were responsible for the insurance and similar scandals. Moreover, the sentiment in favor of the municipal ownership and operation of municipal monopolies had grown more rapidly than even the most careful and competent observers appreciated.

Mr. Hearst's nomination happened at a propitious moment, and from that time on to election day his adherents increased in number and his campaign in effectiveness, and at this writing it is generally believed that he actually secured a plurality of the votes cast in New York on November 7 th.

The significant facts, then, in New York are the substantial plurality given Mr. Jerome in New York County without the aid of any political organization, except one hastily formed for the campaign and disbanded after election, and the vote for Mr. Hearst with the support of an organization, hastily gathered together and inadequately equipped.

In Philadelphia the independent canvass took an entirely different form, but the lesson is no less obvious. The City Party, organized last winter by the Committee of Seventy, was designed to afford the opponents of the "Organization" an opportunity to give voice and effect to their opposition.

At the February election it failed to elect its candidates on the minority ticket because of the help afforded the Democratic candidates by the Republicans. This defeat, however, failed to dampen the ardor of the City Party or to lessen the interest in its purpose. Composed as it was in good part of men who for years had been identified with its predecessor, the Municipal League, and who were enlisted for the fight, whether it required one campaign or many, it pressed forward to defeat the "Organization." When Mayor Weaver's break with the Republican machine brought on the municipal revolution which has startled and commanded the attention of the country, the City Party was in the field, ready to give organized expression to the aroused public sentiment.

The summer months were used in perfecting and extending the work of organization, so that by September there was a fullyequipped municipal party with candidates representative of the widespread demand for a radical change in local political conditions. 
The issue between the City (or municipal) Party and the Republican "Organization" was made all the clearer and more distinct by the withdrawal of the original Republican candidates and the substitution of clean men in their place. It was therefore possible to conduct the campaign on the principles involved without any personal issues to complicate the situation. The fact that the voters of Philadelphia, after a long campaign, clearly and unmistakably endorsed the course of Mayor Weaver and emphasized their rejection of the Republican "Organization" and its autocratic and arbitrary rule of municipal affairs is significant because it plainly showed that the people of Philadelphia could be aroused and could prevail. Doubt on both these lines had been created because of long years of apparent apathy and indifference.

In Cincinnati there were no special revelations of scandals and no sensational exposures of corruption, but the voters, on the sole issue of "boss" rule, defeated the candidates of the Republican organization. Republican Cleveland for the third successive time elected Mayor Johnson, a Democrat, because of its approval of his municipal policy. Toledo elected an independent candidate for Mayor and all his colleagues on the ticket. Boston, or, more properly speaking, the County of Suffolk, elected a District Attorney on an independent ticket against a candidate who was on both the Republican and Democratic tickets. James G. Cutler, who had made an admirable record as Mayor in Rochester, N. Y., was re-elected by an overwhelming majority. Other cities recorded victories of equal significance, if less importance.

I have cited these several instances of independent victories at the November election to show how general was the repudiation of "boss rule," how widespread was the unrest of the people under existing conditions and how strong was the growth of independent municipal sentiment. These instances would be of but limited significance and importance, however, were it not for the fact that they represent the culmination of a series of similar instances. During the year preceding the November (1905) election there had been a very considerable number of important and striking evidences of the independence of the people, of their restlessness under machine rule, and of their desire for a change.

Chicago, which went strongly Republican in November, 1904, swung over to the Democratic side in the mayoralty election in 
April, and in the following November went back to the Republican side on local issues.

In the local elections in Iowa in 1904 the returns from fifty-seven cities showed that in three there was no opposition to the re-election of the incumbents; that in seventeen cities the candidates on independent ticket were elected, and that in nine others the independent tickets were in whole or in part elected. Some of the returns gave no clue as to the partisan character of the nominations, as in Marshalltown, where all the candidates were nominated by petition.

The story of the elections in Indiana in 1904 is equally remarkable. Crawfordsville and Warsaw went Democratic for the first time. In Terre Haute the Republicans defeated the Democratic incumbent. Fifteen cities ordinarily Republican, were carried by the Democrats. These local victories had no important effect on the national elections, as the various communities helped to swell the large Republican vote in the Presidential election.

The local elections in Kansas in 1905 witnessed the election of a number of Democratic mayors in Republican cities. For instance, Kansas City, which gave Roosevelt a plurality of 4,000 in the preceding November, elected a Democratic mayor by 300 . Ottawa, a Republican city, elected a mayor on the municipal ownership issue.

In Pennsylvania the usually Republican cities of Reading, Allentown, Williamsport, Wilkes-Barre, Erie, Titusville, Chester, Johnstown and Monongahela elected Democratic officials. Portland, Ore., in the November election of 1904, gave Mr. Roosevelt an unprecedented majority and elected a Democratic Sheriff by 6,000 plurality.

The Minneapolis election of November, 1904, was, perhaps, the closest in the history of the city, but the result, although the margin was very small, was eminently satisfactory in that it resulted in the election of David P. Jones, the Republican candidate. Although nominated by the Republicans on a direct primary vote, Mr. Jones was distinctly a candidate of the independent element of the city. The things which he stood for in the way of municipal reform were not entirely endorsed by the business men, but the common people understood that he was primarily interested in the welfare of the city and looked first of all to that. It is conceded that his victory was one of the moral forces over the aggregation of the forces of unlawfulness and the saloon men and gamblers and those seeking franchises on inadequate terms. The same campaign committee 
which worked for the Republican candidate for Governor, who was defeated, was hostile to Mr. Jones's election; the result was that the political machine in Hennepin County was completely defeated in that it failed to elect its Republican Governor and failed to defeat Mr. Jones.

The instances recited covering, as they do, nearly two years of time and a large number of communities located in various parts of our country, all point to the conclusion that people are beginning to act upon the doctrine long preached by municipal reformers that municipal affairs must be divorced from state and national issues, and that local questions must be considered without reference to state or national politics.

It does not necessarily follow, however, because the people are to an increasing degree manifesting political independence that there is an accompanying improvement in administrative efficiency. We must look for other evidences to justify the contention that our municipalities are much better governed now than they were thirty, twenty, or even ten years ago. Very often an independent victory results in a temporary loss of efficiency, because of the introduction of new men into public service unacquainted with the detailed needs of a community and unfamiliar with the administration of public affairs. Communities, however, are usually willing to pay this price if they can be assured of the honesty and public spirit of those whom they have put into office. Chicago affords the most striking illustration of the fact that it is possible to have a very large measure of representative government and municipal reform and yet a comparatively inefficient administration.

The functions discharged by the average American municipality have very greatly increased during the past generation. A comparison of the budgets of the present year with those of the early 7o's, let us say, in any American city would disclose the fact that the cities are now engaged not only in more extensive undertakings along already established lines, but are entering into many new fields of endeavor unthought of at that time. So rapid and engrossing has been municipal development in the last few decades that the average man, even the student, has failed to appreciate how important a factor in our daily life the city has become.

This tendency has unconsciously, but none the less effectively, worked mightily for improvement in the administration of municipal 
affairs, so that it is not an uncommon thing to find recorded, as has been recorded in New York City during the past year, a denunciation of political methods and an appreciation of the improvement in the administrative service of the city.

To be sure, improvement along these lines cannot be measured with a yardstick, nor weighed on the scales, but must be gathered from a multiplicity of facts and expressions of those possessed of a gift of comparison and of a sufficiently long memory. For some months past I have followed with much interest the change in the tone of commentators on municipal affairs and the titles given to magazine articles and editorials. All tend to confirm the conclusion I have long held that a new spirit is abroad in our cities and that the average worker for municipal improvement is disposed to take a hopeful view of the situation, and that conditions really are improving.

As indicating the present day view of municipal conditions, I might quote the titles of some recent editorials and articles: "The Day Dawns," "Conditions are Getting Better," "The Growing Improvement in Municipal and State Government," "A Municipal Easter at Hand," "The Rising City Tide," "Municipal Housecleaning Elsewhere," "The General War on Machines," "The New Note in Politics," "A Year of Municipal Advances," "City Government Growing Better." Moreover, within the past year I have sought the views of a number of observers located in different parts of the country, asking them specifically whether my own conviction that there was a slow but steady improvement in American municipal conditions was justified by their own observation and experience.

The replies were uniformly in the affirmative. While it is true many felt that the local conditions with which they were most familiar showed little or no change, nevertheless their judgment was that conditions elsewhere were improving. This apparent paradox is explained by the fact that as to their local conditions they lacked the necessary perspective; as to events in other communities than their own, they saw things in a more correct perspective.

There is no denying, even if one were disposed to do so, that President Roosevelt's attitude, as Mayor Weaver, of Philadelphia, pointed out in a recent speech, has helped mightily in creating a public sentiment intolerant of dishonesty and chicanery in public affairs. I have been surprised at the unanimity of expression on the part 
of those Irom whom I have inquired that the activity of the governors in the Central West, along what are commonly called "good government" lines are primarily and directly due to the President's example.

The attitude of Secretary Root in the Philadelphia campaign, of Secretary Taft in the Ohio campaign and of Secretary Bonaparte in the Maryland campaign afford additional evidence of the growth of independent thought in the consideration of local matters. Until within the past few years were a Cabinet officer to attack, even by indirection, his party organization in any community, no matter how corrupt or malodorous it might have become, it would have been considered heresy. Now it seems to be a popular move for them and for others high in office to throw their influence upon the side of decency and honesty.

Municipal progress is manifested in still a different direction, namely, that of concrete reforms. As never before our municipalities are giving thoughtful and careful consideration to their charters. We are passing through a period of widespread dissatisfaction with the existing inadequate legislation governing our American cities. The demand for home rule grows apace. One by one our cities are achieving it. Where this is not possible because of constitutional limitations, improved charters are coming to be adopted and amendments to them resisted because of disinclination to state interference. To mention only by name the various cities during the past two or three years that have had under consideration either a new charter or amendments to existing instruments would be to fill two or three pages of this volume. It is true that not all the changes have been for the better, but our communities are feeling the need for change, and as this grows there will be steady improvement, with only such setbacks as the desire for experimentation or inexperience may cause.

Ballot reform has become an issue of far-reaching importance. The last election served to give it renewed force and prominence. The demand is becoming general that each voter shall mark the name of each candidate he desires to vote for. Hand in hand with the demand for ballot reform is the growth of interest in nomination reform. The conviction is very general that the present systems of nomination prevailing in the majority of the states are antiquated and better adapted to giving expression to the wishes of 
the few than to expressing the will of the majority. In some states new primary election laws have been enacted and will go into force during the coming year, notably in Illinois and Wisconsin. Nomination reform is also a prominent question before the voters of New York, Pennsylvania, Ohio, Indiana, Wisconsin and Michigan; and most of the Western States have already made some tentative effort in the solution of the problem.

The whole subject of the municipal ownership and operation of municipal monopolies has become a paramount issue in nearly all of our larger communities. The Chicago election of 1905 turned upon the attitude of the candidates on this question. Mr. Hearst's phenomenal campaign in New York was largely based on the demand for municipal ownership, and was unquestionably helped by the rapidly growing conviction that municipal monopolies should be administered for the benefit of the many rather than for the profit of the few. Mayor Johnson's repeated successes in Cleveland are largely due to the same cause; also to the additional fact that he is giving the people of that city an increasingly efficient government.

Just what is to be the outcome of this demand for municipal ownership it is impossible to forecast, but there can be no question of the interests of the people in it and of the further fact that it is destined to increase still further their interest in municipal problems.

Another evidence of municipal progress is the growth in the number of courses in municipal government offered not only in our institutions of higher learning but in our high, secondary and elementary schools. A decade ago practically no instruction in these subjects was given. Now at least twenty colleges and universities offer more or less elaborate courses, and the subject is treated more or less fully in as many more. Instruction in civics is becoming a pressing question among educators, and the interest manifested in the report of the National Municipal League Committee on Instruction in Secondary and Elementary Schools may be taken as a fair index of the interest in the subject.

I have omitted, up to this point, making any reference to the growth in numbers and influence of the organizations wholly or in part interested in the considerations of municipal questions. Now, more than ever, this subject is receiving consideration at the hands of chambers of commerce, boards of trade and other similar bodies. as well as from a rapidly-lengthening list of municipal leagues, good government and city clubs, and civic associations. 
As I have already said, the progress of interest and activity in municipal affairs cannot be measured by any ordinary standard; but those who have given the subject thoughtful attention during the past fifteen or twenty years are strongly of the opinion that public interest is being developed along wholesome and encouraging lines and that the years 1904 and 1905 may properly be considered as recording wider and more substantial progress than any two preceding years. 